\title{
Deformation Process and Mechanism Analyses of a Rock Slope Based on Long-Term Monitoring at the Pubugou Hydropower Station, China
}

\author{
Xuefeng Mei $\mathbb{D},{ }^{1}$ Nengfeng Wang $\mathbb{D},{ }^{2}$ Guotao Ma, ${ }^{3}$ Jie Wang, ${ }^{4}$ Yan Wang, ${ }^{3}$ Jianli Wu $\mathbb{D},{ }^{3}$ \\ Mei Han $(1),{ }^{5}$ and Bin $\mathrm{Cai}^{2}$ \\ ${ }^{1}$ School of Civil and Architectural Engineering, Shandong University of Technology, Zibo 255049, China \\ ${ }^{2}$ Power China Chengdu Engineering Corporation Limited, Chengdu 610072, China \\ ${ }^{3}$ Faculty of Geosciences and Environment Engineering, Southwest Jiaotong University, Chengdu 610031, China \\ ${ }^{4}$ Sichuan Institute of Geological Engineering Investigation Group Co., Ltd., Chengdu 610072, China \\ ${ }^{5}$ School of Mathematics, Southwest Jiaotong University, Chengdu, Sichuan 610031, China
}

Correspondence should be addressed to Nengfeng Wang; 2004039@chidi.com.cn and Mei Han; hanmei@home.swjtu.edu.cn

Received 15 December 2020; Revised 7 January 2021; Accepted 15 January 2021; Published 13 February 2021

Academic Editor: Bin Gong

Copyright (C) 2021 Xuefeng Mei et al. This is an open access article distributed under the Creative Commons Attribution License, which permits unrestricted use, distribution, and reproduction in any medium, provided the original work is properly cited.

This paper presents a typical $450 \mathrm{~m}$ high rock slope in a highly jointed and fractured rock mass at Pubugou (PBG) hydropower station on the Dadu River. We established a set of multiphase field geological survey combined with GPS, inclinometers, and piezometer monitoring system to analyze the deformation and failure mechanism of rock slope. The results show that smallscale excavation in road construction disrupted the balance of the Pubugou rock slope (PBGRS), and several local retrogressive failures occurred at the toe. Monitoring data regarding surface and subsurface movements show that the PBGRS is stable as a whole. The deformation concentrated mainly in the loosened fractured zone, which was a feature with sliding-compression cracking. Highly loosened rock mass was the predominant factor affecting the stability of the PBGRS, while the role of reservoir water level fluctuation, though positive, was not significant. Overall, the PBGRS still has a high potential for further development, especially in the slope's upper zone. To reinforce the slope, measurements mainly consist of the concrete frame combined with anchor cables constructed on the slope. In this study, the analysis was carried out of pre- and postreinforcement measure slope stability with numerical simulation, and safety factor increased from 1.09 to 1.21 . This study's findings have important implications to the analytical method and reinforcement design with geological settings like that of the PBGRS.

\section{Introduction}

The Western Sichuan Province is located on the eastern edge of the Tibetan Plateau and is rich in hydropower resources. Over the past few decades, there are more than 20 largescale hydropower projects (Table 1), which mainly settled on the three major rivers $[1,2]$. Usually, these areas are deep down cutting river valleys, with high stresses, active tectonic environment, and loosened rock mass. Therefore, rock slope stability has been the most essential engineering problem [39]. Many studies pointed out that slope stability can pose a high risk to the operation of the hydropower station system [10-15]. The disaster hazard chains that result from slides, especially the formation and outburst barrier lakes, often generate much more threats than slope failure [16-18]. Moreover, the slide deposits could result in the capacity reduction of effectiveness. Therefore, it is essential to understand these unstable slopes located in the reservoir regions, particularly their possible failure modes.

In many studies, several influencing factors, such as excavation [19], heavy rainfall [20-22], and water level fluctuation in the reservoir [23-26], could highly affect the stability of the bank slope. Some reported cases showed that minor-scale excavations during road construction could also cause a large deformation of rock slopes [27, 28]. Many researchers prefer to analyze the dynamic changes of seepage 
TABLE 1: Engineering geological problems of hydropower station slope in southwest China.

\begin{tabular}{|c|c|c|c|c|c|c|c|}
\hline $\begin{array}{l}\text { Name of the } \\
\text { hydropower station }\end{array}$ & $\begin{array}{l}\text { Natural slope } \\
\text { height }(\mathrm{m})\end{array}$ & $\begin{array}{c}\text { Slope } \\
\text { gradient }\left({ }^{\circ}\right)\end{array}$ & $\begin{array}{c}\text { Dam } \\
\text { height }(\mathrm{m})\end{array}$ & $\begin{array}{l}\text { Total storage } \\
\text { capacity }\left(\mathrm{m}^{3}\right)\end{array}$ & $\begin{array}{l}\text { Location of the } \\
\text { slope }\end{array}$ & Lithology & $\begin{array}{c}\text { Engineering } \\
\text { geological issues }\end{array}$ \\
\hline Jinping & $>1000$ & $>40^{\circ}$ & 305 & $77.6 \times 10^{9}$ & Left bank & $\begin{array}{c}\text { Marble, } \\
\text { sandstone }\end{array}$ & $\begin{array}{l}\text { Deep rupture and } \\
\text { creep }\end{array}$ \\
\hline Xiluodu & $300-350$ & $>60^{\circ}$ & 276 & $128.0 \times 10^{9}$ & $\begin{array}{l}\text { Left and right } \\
\text { bank }\end{array}$ & Basalt & Bedding rockslide \\
\hline Shuangjiangkou & $>1000$ & $>43^{\circ}$ & 312 & $76.0 \times 10^{9}$ & $\begin{array}{c}\text { Left and right } \\
\text { bank }\end{array}$ & Granite & Deep rupture \\
\hline Xiangjiaba & 350 & $>50^{\circ}$ & 161 & $51.6 \times 10^{9}$ & Left bank & Sandstone & Deep rupture \\
\hline Baihetan & $400-860$ & $>42^{\circ}$ & 289 & $206.0 \times 10^{9}$ & Left bank & Basalt & Deep rupture \\
\hline Xiaowan & $700-800$ & $>47^{\circ}$ & 294 & $150.0 \times 10^{9}$ & Right bank & Gneiss & Bedding rockslide \\
\hline Nuozhedu & 800 & $>43^{\circ}$ & 261 & $237.0 \times 10^{9}$ & Spillway & Granite & $\begin{array}{l}\text { Weathering, } \\
\text { fracture }\end{array}$ \\
\hline Dagangshan & $>600$ & $>40^{\circ}$ & 210 & $7.4 \times 10^{9}$ & Right bank & Granite & Deep rupture \\
\hline Huangjingping & $>300$ & $>25^{\circ}$ & 95 & $1.4 \times 10^{9}$ & $\begin{array}{l}\text { Left abutment } \\
\text { intake slope }\end{array}$ & Granite & Deep rupture \\
\hline Pubugou (this paper) & 450 & $>35^{\circ}$ & 186 & $53.9 \times 10^{9}$ & Right bank & Tuff & Deep rupture \\
\hline
\end{tabular}

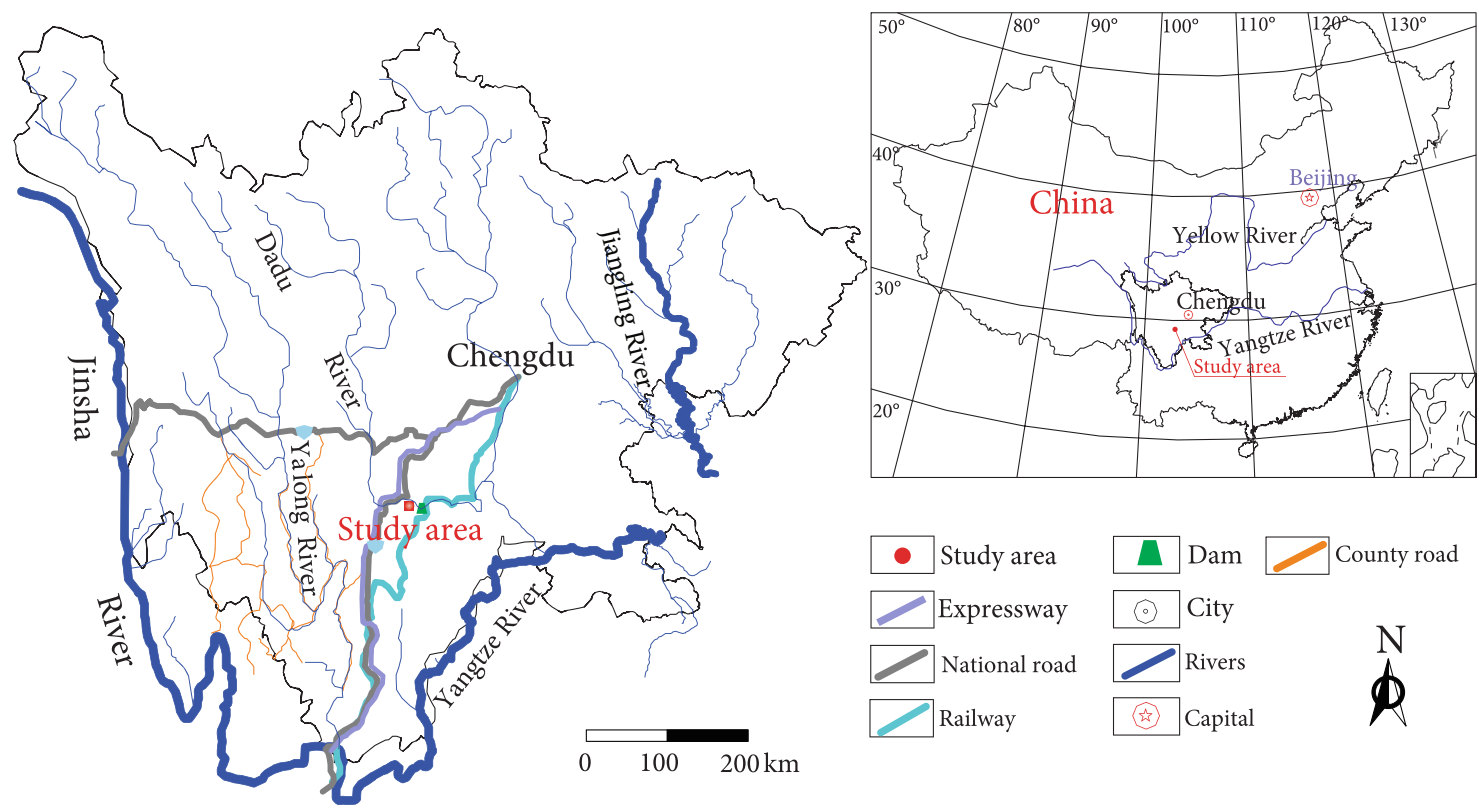

FIGURE 1: Location map of the study area and its nearby cities.

flow in groundwater by numerical simulation. However, a special case study from the Guantangkou landslide [29, 30] reveals that the fluctuation of reservoir water level has no significant effect on the slope stability. Due to severe slope failure consequences [31-35], most slopes in large hydropower stations need to be reinforced. Therefore, a detailed stability analysis of these slopes is required in engineering design, such as ensure the shear surface, slide direction, and geomechanical parameters. These parameters can usually be obtained through field surveys or laboratory tests, but slope stability results have huge parameter uncertainty because of sample disturbance and method errors [36]. Besides, due to the indoor slope scale model test's size limitation, the results may differ significantly from the actual responses. In recent years, although aerial and airborne remote sensing technologies provide new methods for landslide research [37-39], these methods require a lot of manpower, cost-effectiveness [40-42], and topography limitation of covered by dense vegetation $[43,44]$. The key point is that remote sensing cannot obtain deep deformation characteristics, and this evidence is the most critical parameter for determining reinforcement measures.

This paper focuses on the stability of a rock slope only $780 \mathrm{~m}$ from the dam of the Pubugou hydropower station in 

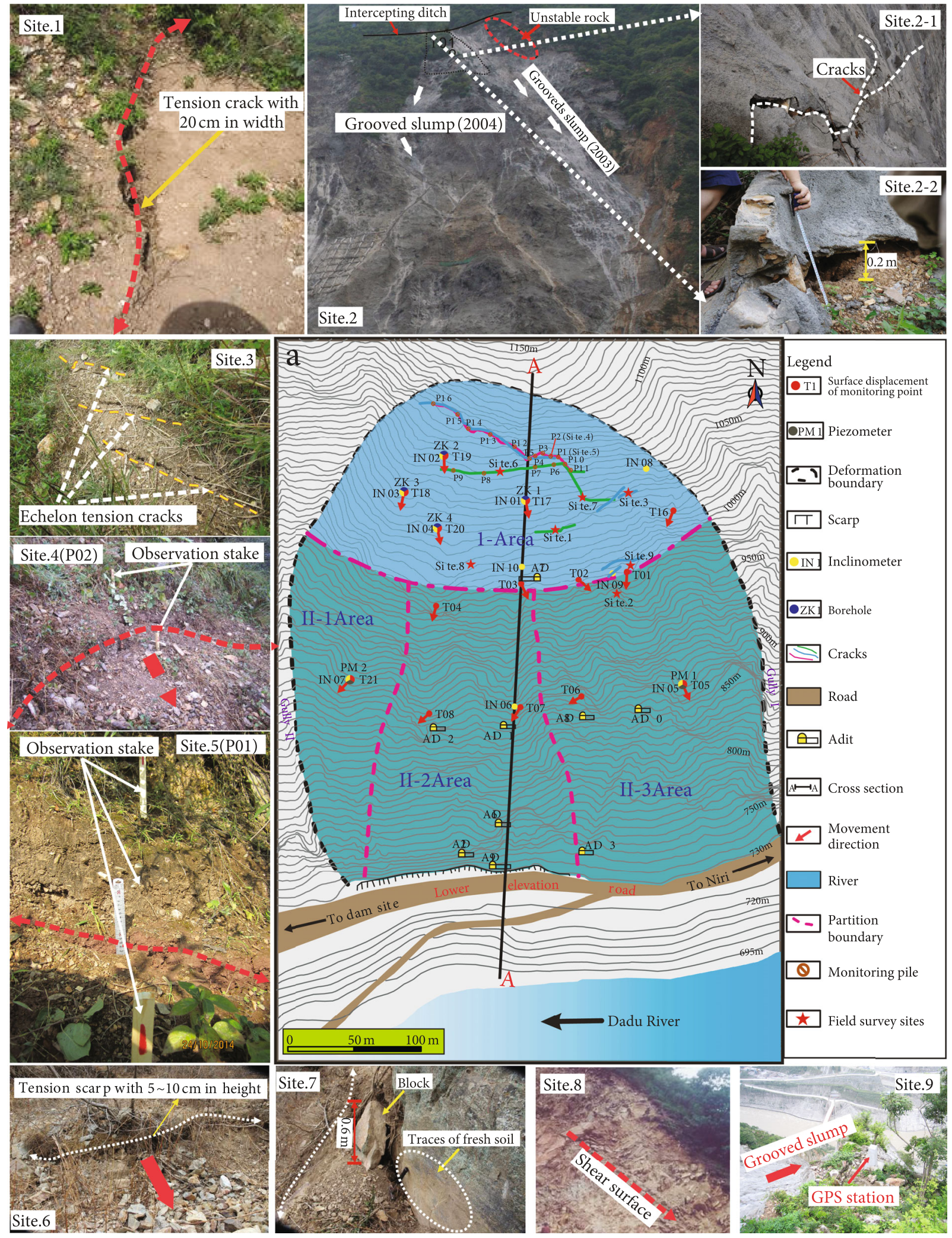

FIGURE 2: Topographic map of the PBGRS, monitoring locations and survey points; Site.1: tensile cracks, the strike is N29 ${ }^{\circ}$ E, total length is nearly $150 \mathrm{~m}$, and the pull-out width is generally $0.5-2 \mathrm{~cm}$, of which the largest pull-out width is $10 \mathrm{~cm}$; Site.2: the grooved slumps and cracks; Site.3: echelon tension cracks; Site.4: the cracks of P02; Site.5: the cracks of P05; Site.6: the strike is near SN, sinking 5-10 cm; Site.7: the strike is $\mathrm{N} 29^{\circ} \mathrm{E}$, the depth is $1.0 \mathrm{~m}-1.2 \mathrm{~m}$, and fresh yellow attached soil can be seen on the bedrock wall; Site.8: characteristics of the shear surface along a slope; Site.9: the grooved slumps and GPS monitoring point No.T2. 


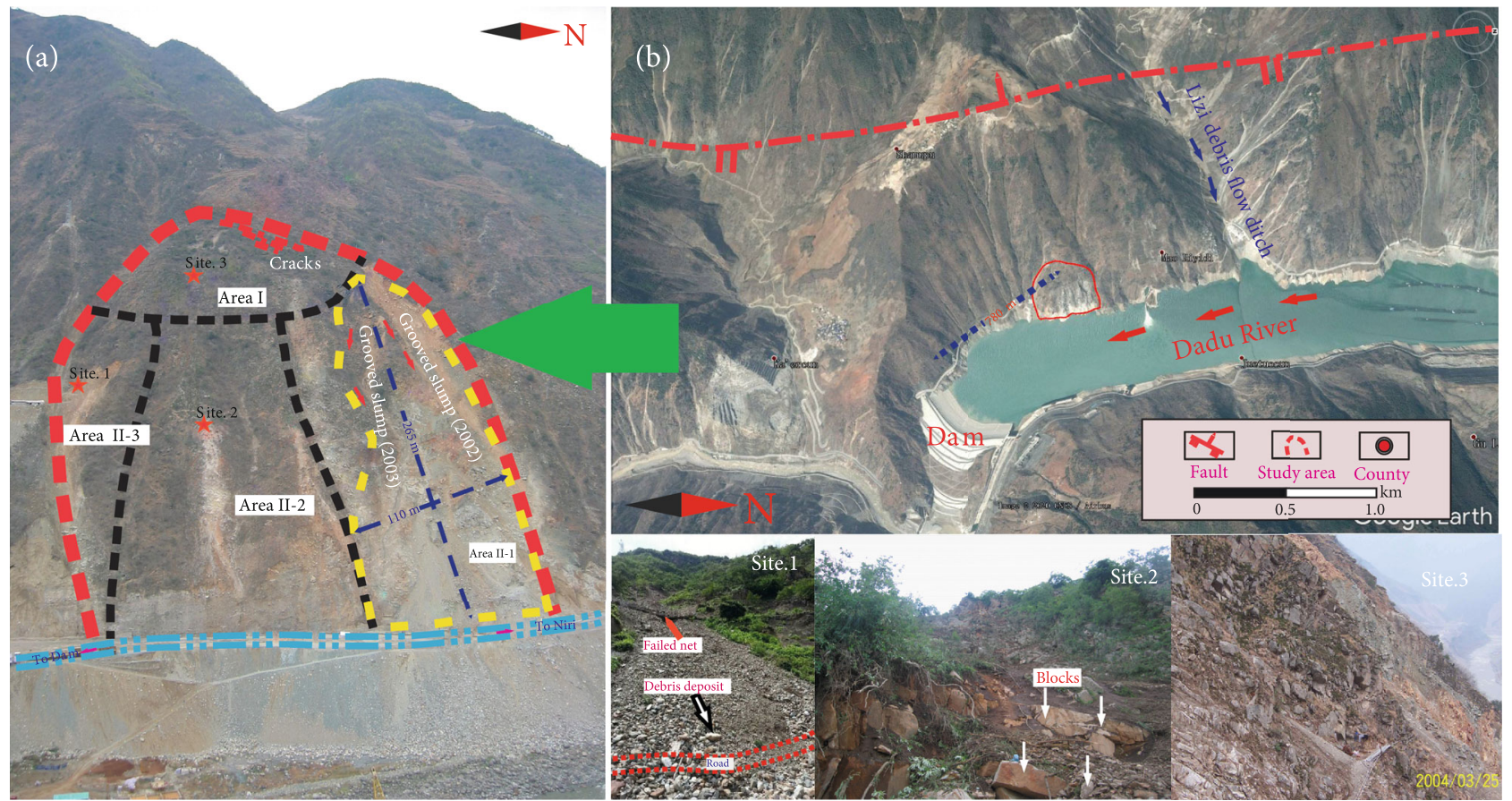

FIGURE 3: Field observations of the PBGRS: (a) overview of the PBGRS; (b) relative position of the fault and PBGRS; Site.1: slippery debris blocking the road at gully II; Site.2: small-scale collapse; Site.3: fractured and highly permeable rock mass.

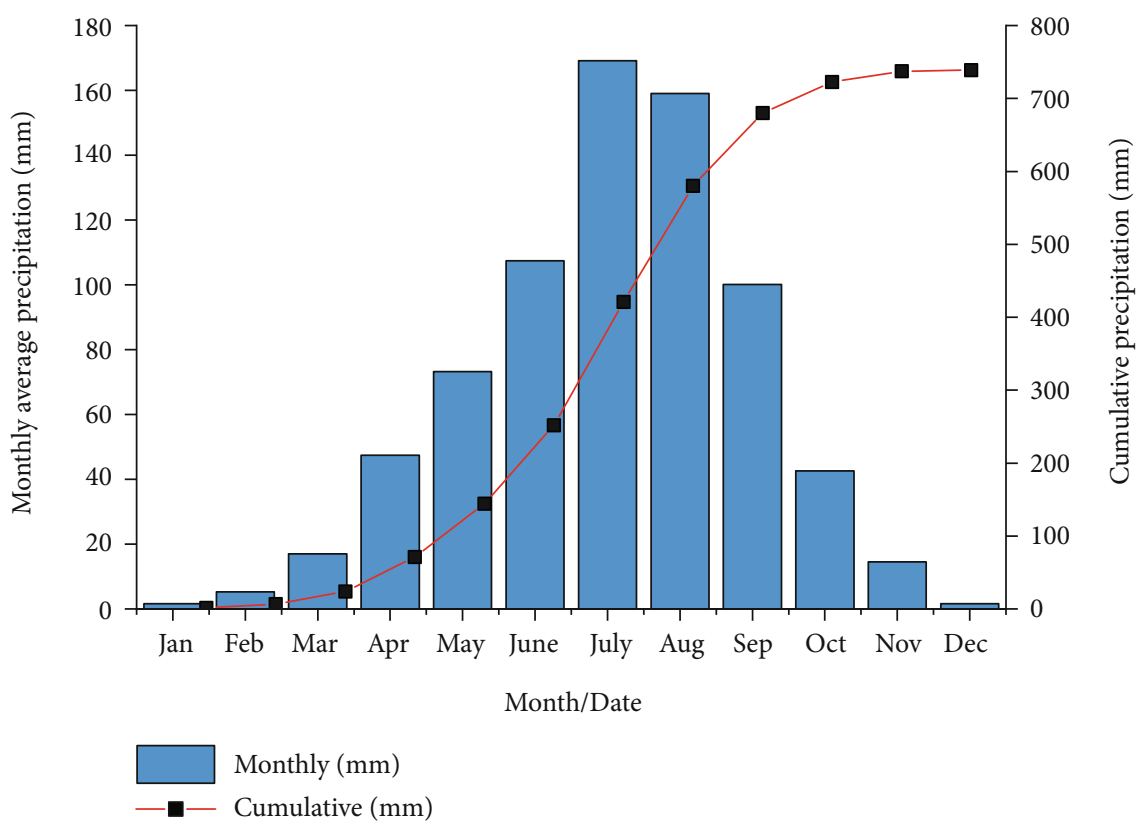

FIGURE 4: Distribution of monthly average precipitation.

Sichuan Province (Figure 1). Field investigation, deformation monitor, and numerical analysis were carried out to determine the causes and deformation mechanism of the PBGRS. The analysis was carried out with the pre- and postreinforcement measures in numerical simulation to evaluate the effectiveness of the engineering measures. According to these results, the slope's possible evolution mode is proposed, and the development tendency of the PBGRS is assessed.

\section{Methodology}

The PBGRS was investigated using field mapping, geological drilling, in situ monitoring, and numerical modeling. The field survey and the topographic map of $1: 1000$ are comprehensively used to determine the deformation range's boundaries and deformation characteristics (Figure 2). The drilling sampling was performed at several important locations to 
TABLE 2: Characteristics of the rock mass in the drill holes. Their locations are shown in Figure 2.

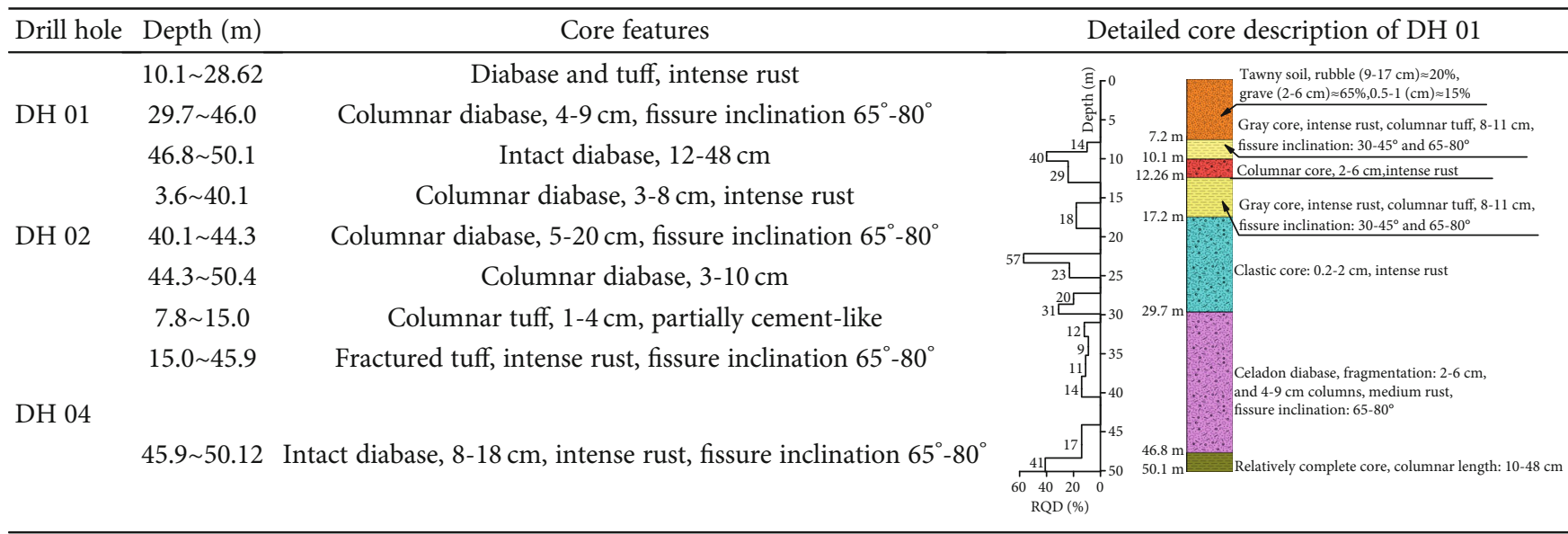
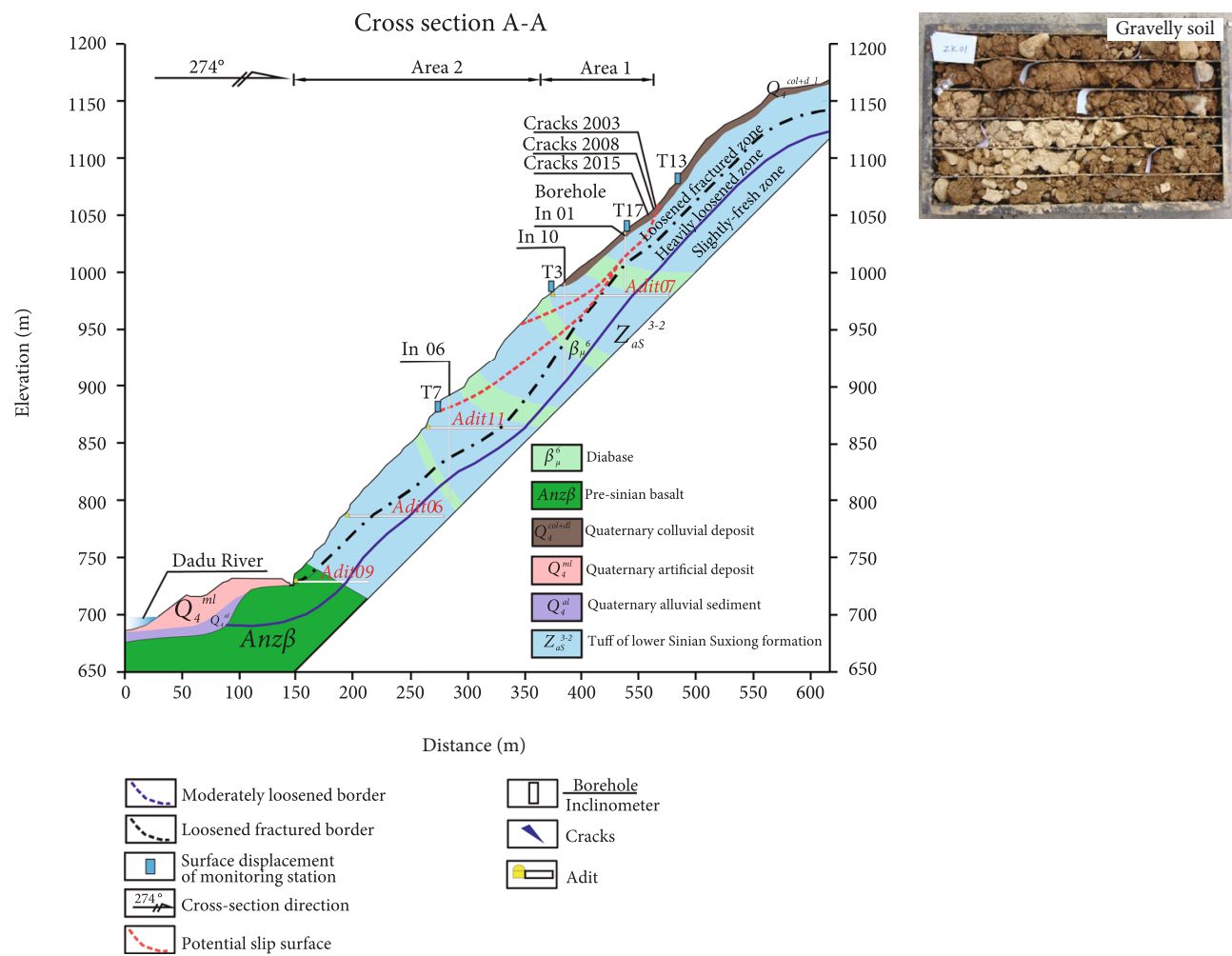

(a)

(b)

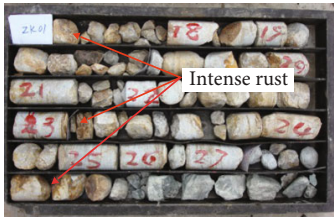

(c)

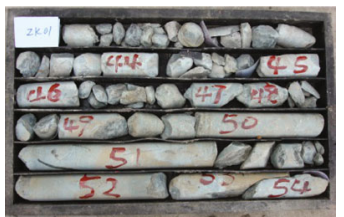

(d)

FIGURE 5: (a) Engineering geological profile of the PBGRS; (b) photo of gravelly soil; (c) intense rusty short columnar core of loosened fractured zone; (d) intact core of heavily loosened zone.

obtain more information about the properties of the stratum and the features of the rock mass. Several filed investigations were conducted from 2003 to 2015, mainly including recording the macrodeformation characteristics of ground cracks in the study area, such as new cracks and the expansion of old cracks. A total of 486 crack morphology were measured to analyze the slope deformation characteristics. The monitor installed on the study area recorded the following: (i) a total 

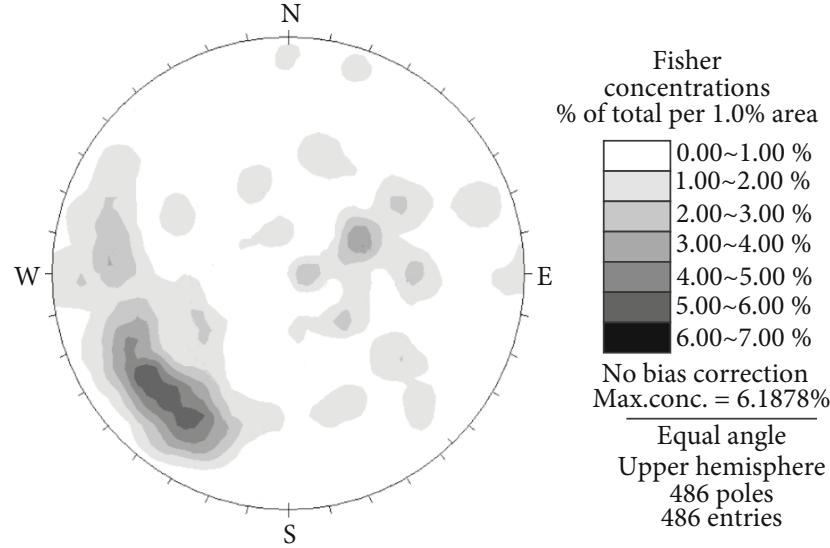

Figure 6: Contour plots of basal joints in the horizontal adit.

of 12 GPS devices were used from November 2009 to September 2014 to measure surface displacements, (ii) deformation characteristics at different depths can be explained by 10 inclinometers from November 2009 to March 2019, and (iii) a total of 2 piezometers are used to analyze the influence of reservoir water level on slope deformation. Figure 2 shows the situations of the monitoring sites. A numerical analysis of pre- and postreinforcement measure slope stability was conducted, and the safety factor along the observed sheer surface was calculated.

\section{Project Background}

The PBG hydropower station is located in Hanyuan County, Sichuan Province, China (Figure 1). The maximum design dam height is $186 \mathrm{~m}$ on Dadu River. It creates a reservoir of $53.9 \times 108 \mathrm{~m}^{3}$ at the normal pool level of $780.00 \mathrm{~m}$. The power station's designed capacity is $3300 \mathrm{MW}$, and the annual power generation is $145.8 \times 108 \mathrm{kw} \cdot \mathrm{h}$. The reservoir was first stored in November 2009 and reached its highest water level in October 2010. The PBRGS is located $780 \mathrm{~m}$ upstream of the dam axis on the right bank of the hydropower station.

3.1. Engineering Geology. The study area is located in the transition zone between the western edge of the Sichuan basin and the Hengduan Mountains and is situated at the Hanyun Gorge, which is one of the Three Gorges by the Dadu River (namely, Hanyuan Gorge, Jinkou Gorge, and Ebian Gorge). The regional tectonic setting is the HanyuanZhaojue left-hand thrust inverse fault belt $\left(\mathrm{SN} / \mathrm{E} \angle 60^{\circ}-80^{\circ}\right)$, with $120 \mathrm{~km}$ in length and $20-60 \mathrm{~m}$ in width. This fault belt was inactive since the Late Pleistocene (Figure 3(b)).

Hanyuan belongs to the subtropical climatic zone in the mountains and southwest of Sichuan. The mountains and valleys are highly undulating, with significant vertical changes and concentrated rainfall. The annual average temperature is $17.7^{\circ} \mathrm{C}$, the highest temperature is $40.9^{\circ} \mathrm{C}$, and the extreme minimum temperature is $-3.3^{\circ} \mathrm{C}$. The average annual evaporation is $1395.6 \mathrm{~mm}$. The average relative humidity is $68 \%$, the maximum wind speed is $15.3 \mathrm{~m} / \mathrm{s}$, the average annual precipitation is $748.4 \mathrm{~mm}$, and the maximum daily precipitation is $168.2 \mathrm{~mm}$. The precipitation is concentrated from May to October and accounts for $80-90 \%$ of the annual (Figure 4).

3.2. Basic Description of the PBGRS. The PBRGS area's elevation is between $730 \mathrm{~m}$ and $1150 \mathrm{~m}$, and the maximum elevation difference is approximately $420 \mathrm{~m}$. The slope gradient is nearly $50^{\circ}$ below the 980 ma.s.l, and nearly $40^{\circ}$ upper the 980 ma.s.l. The geomorphological pattern is a comb-like type. The slope aspect is approximately EW, and gullies on both sides were $10 \mathrm{~m}$ to $35 \mathrm{~m}$. The maximum length and width dimensions of the PBGRS are $400 \mathrm{~m}$ and $360 \mathrm{~m}$, respectively. It has an area of approximately $0.15 \mathrm{~km}^{2}$. According to the topography, rock mass features, and deformation characteristics, the entire research area can be divided into two parts: the upper unstable dangerous rock mass area which is above 980 ma.s.l (area I) and the lower unstable area that is below 980 ma.s.l (area II). Among them, the gradient in area I is relatively gentle. There is a quaternary loose accumulation layer with an average thickness of $10 \mathrm{~m}$. The outcrop of the bedrock has a fragmentation-debris structure (Site.3 in Figure 3). Area II includes three subzones according to the characteristics of deformation and failure. The II- 1 area disintegrated from the toe in May 2003 and formed a tension fracture groove, and the volume of this part is approximately $1000 \mathrm{~m}^{3}$. Area II-2 is a potential failure part, which is continuously expanding in the retrogressive pattern since 2003. The area from the right boundary of area II-2 to gully II is called II-3, which found a residual ancient collapse body in this area.

3.3. Geological Drilling and Rock Mass Properties. The bedrock exposed in the region is the rhyolite tuffs of the Suxiong Formation in the Sinian and the shallow metamorphic basalts in the pre-Sinian. During the long renovation process, these rocks have been altered by river incision and a series of tectonic events (such as the Yanshan movement and Himalaya orogeny), thus creating very complex structures [45, 46]. According to the lithostratigraphy and structure of the PBGRS which were obtained by drill holes and site investigations, the slope's rock mass has been extensively fractured. The degree of fracturing and jointing increases toward the ground surface, resulting in an increasingly loosened rock mass (Table 2, and detailed core description of DH 01). As shown schematically in the cross-section (Figure 5(a)), except for gravel soil a few meters thick below the surface (Figure 5(b)), the loosened fractured zone extends to a depth of about 20-60 m, and the heavily loosened zone extension depth is approximately $65-90 \mathrm{~m}$. Drilling lithology samples indicate that the drill core sample of the loosened fractured zone is fragmental with a short column, and the crack surface is severely rusty (Figure 5(c)). In contrast, that of the heavily loosened zone is relatively intact (Figure 5(d)). The borehole sampling's core fracture angle indicates that steep dip cracks (inside or outside the steep slope) are absolutely dominant, and rock debris fills with the gaps reflects the mutual displacement between the blocks. In addition, the extended depth of the loosened fractured zone is thick at high 


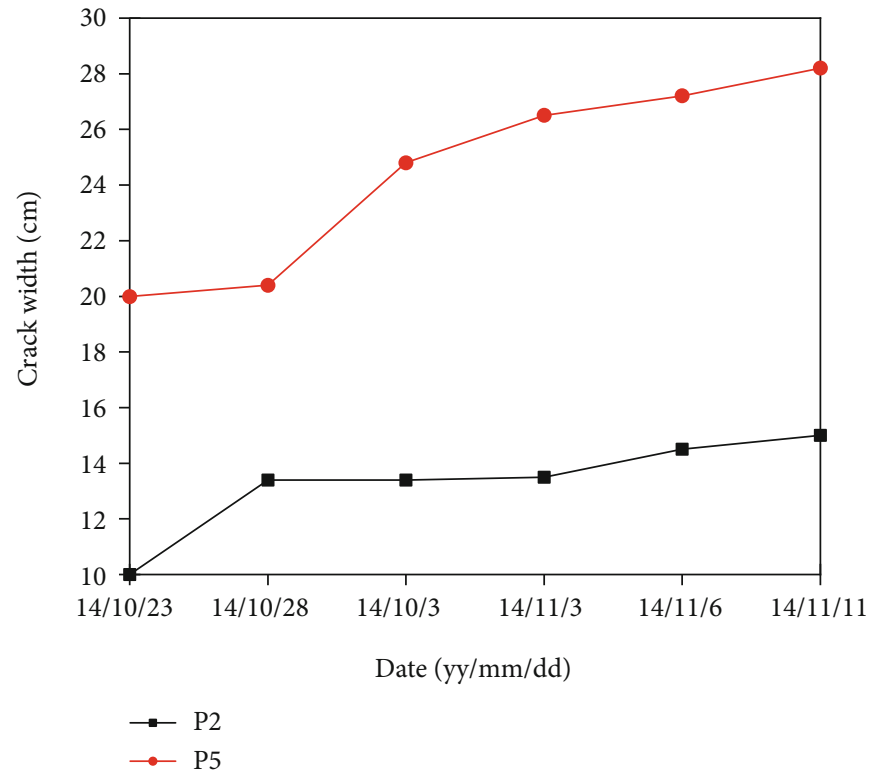

FIGURE 7: Crack width changes with time.

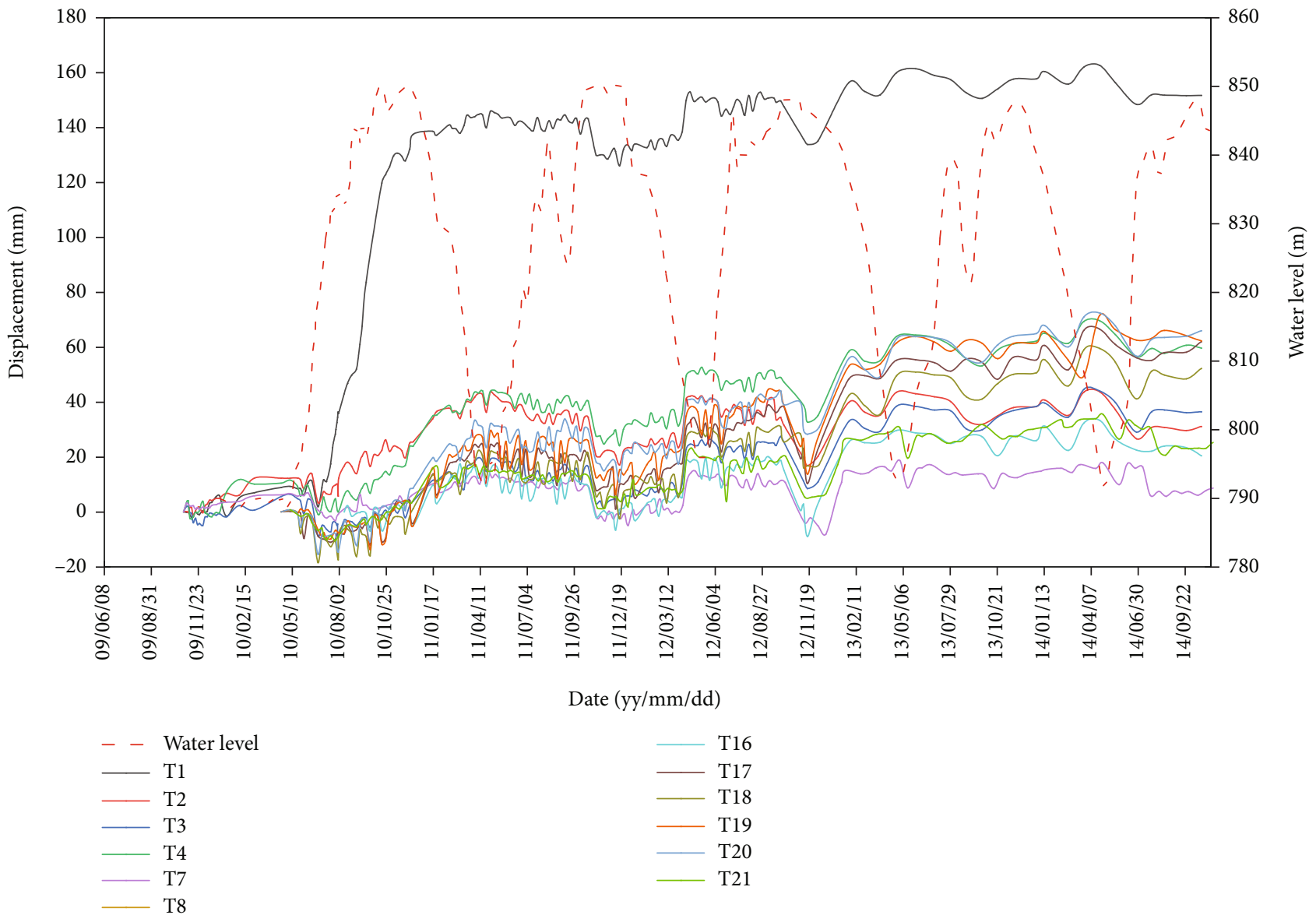

FiguRE 8: The surface movement monitoring and reservoir water level result. 


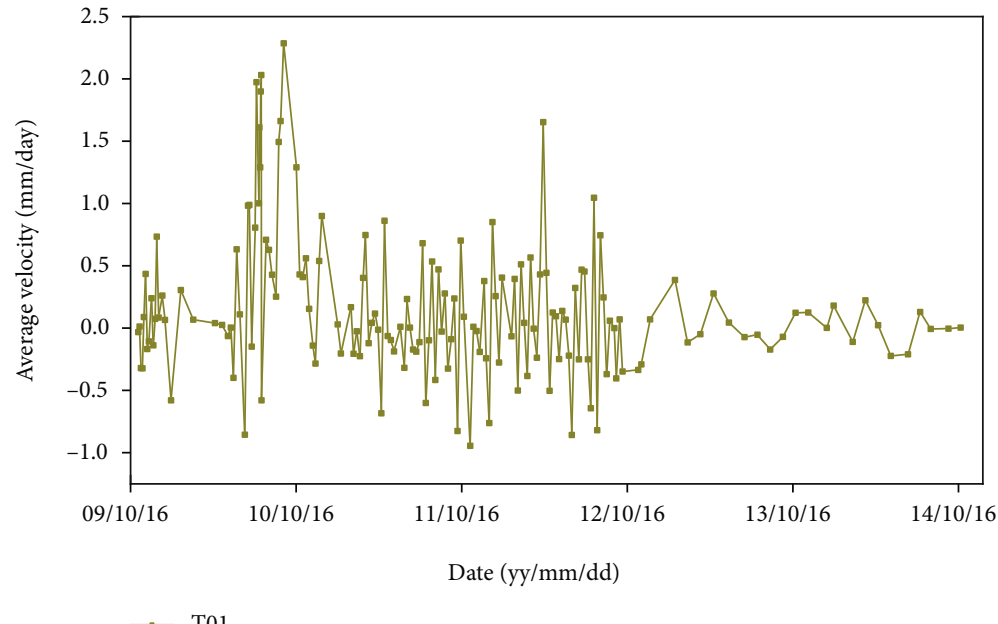

(a)

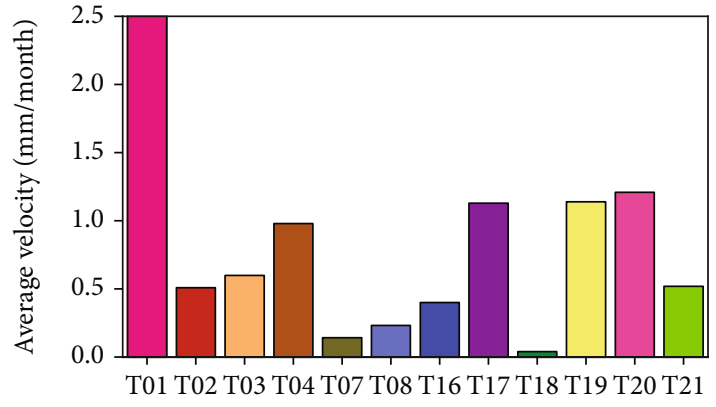

(b)

FIGURE 9: Comparison of average displacement velocities from GPS monitoring: (a) daily average velocities of T01; (b) monthly average velocities.

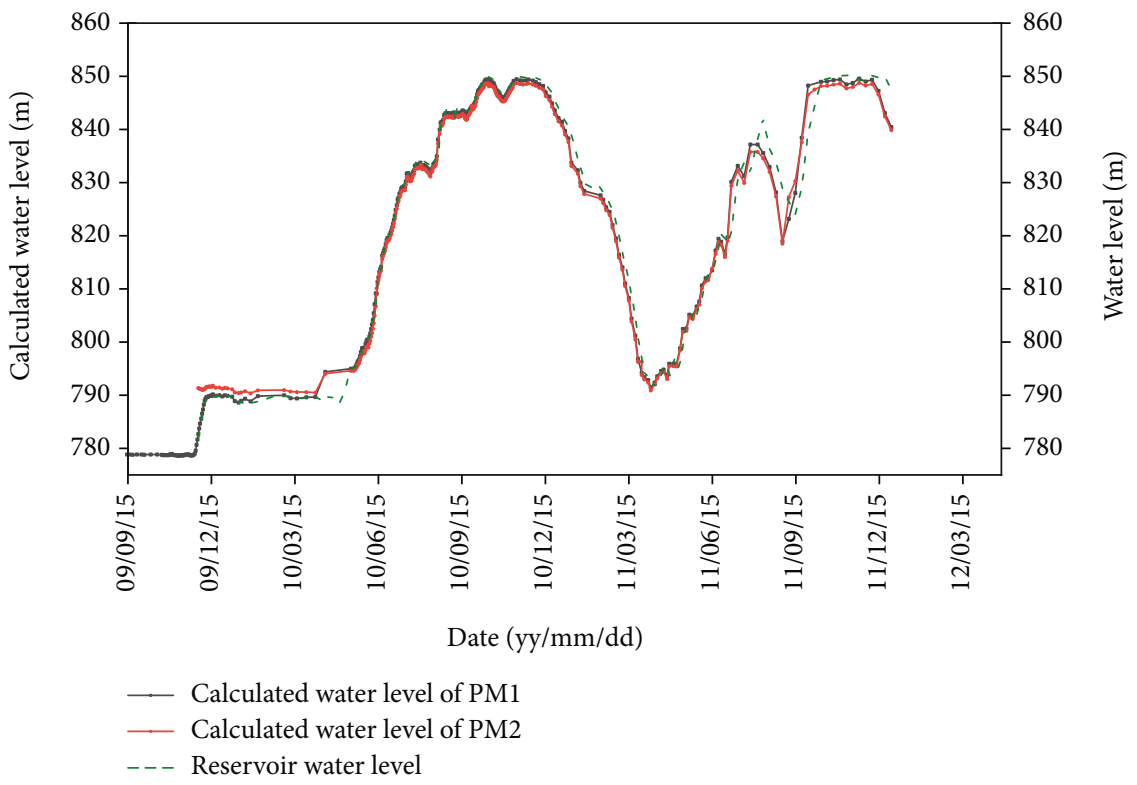

FIGURE 10: Comparison of calculated water level of piezometers and the reservoir levels.

elevations. The entire slope's rock mass is extensively fractured and highly permeable; stable groundwater levels were not found during field investigations.

The basal joints are composed of various primary and tectonic fissure types at the most basic level and randomly developed in the rock mass $[47,48]$. In this study, we investigated the distribution of approximately 486 basal joints in the adits (Figure 6). The results showed that the discontinuities on the PBRGS are abundant; no persistent and dominating discontinuity trends were identified. The most basal joints account for only $5.1 \%$ of the total number of cracks, i.e., 25 basal joints.

\section{Brief History of Instabilities}

The earliest deformation history of the PBGRS dates back to February 2003. Several very small-scale collapse sites in area II-1 have been observed (Figure 3(a)), induced by excavation during the construction of a road, and it did not attract much attention. Subsequently, in May 2003, a heavy rainfall induced a collapse with more than $1000 \mathrm{~m}^{3}$. The retrogressive disintegrations failed towards the upslope and formed the first collapse groove (Site.2 in Figure 2). The depth of the collapse groove is about $12 \mathrm{~m}$. By the end of 2004, the range of instability had expanded, and a second collapse groove had 
Cumulative displacement (mm)

Cumulative displacement (mm)

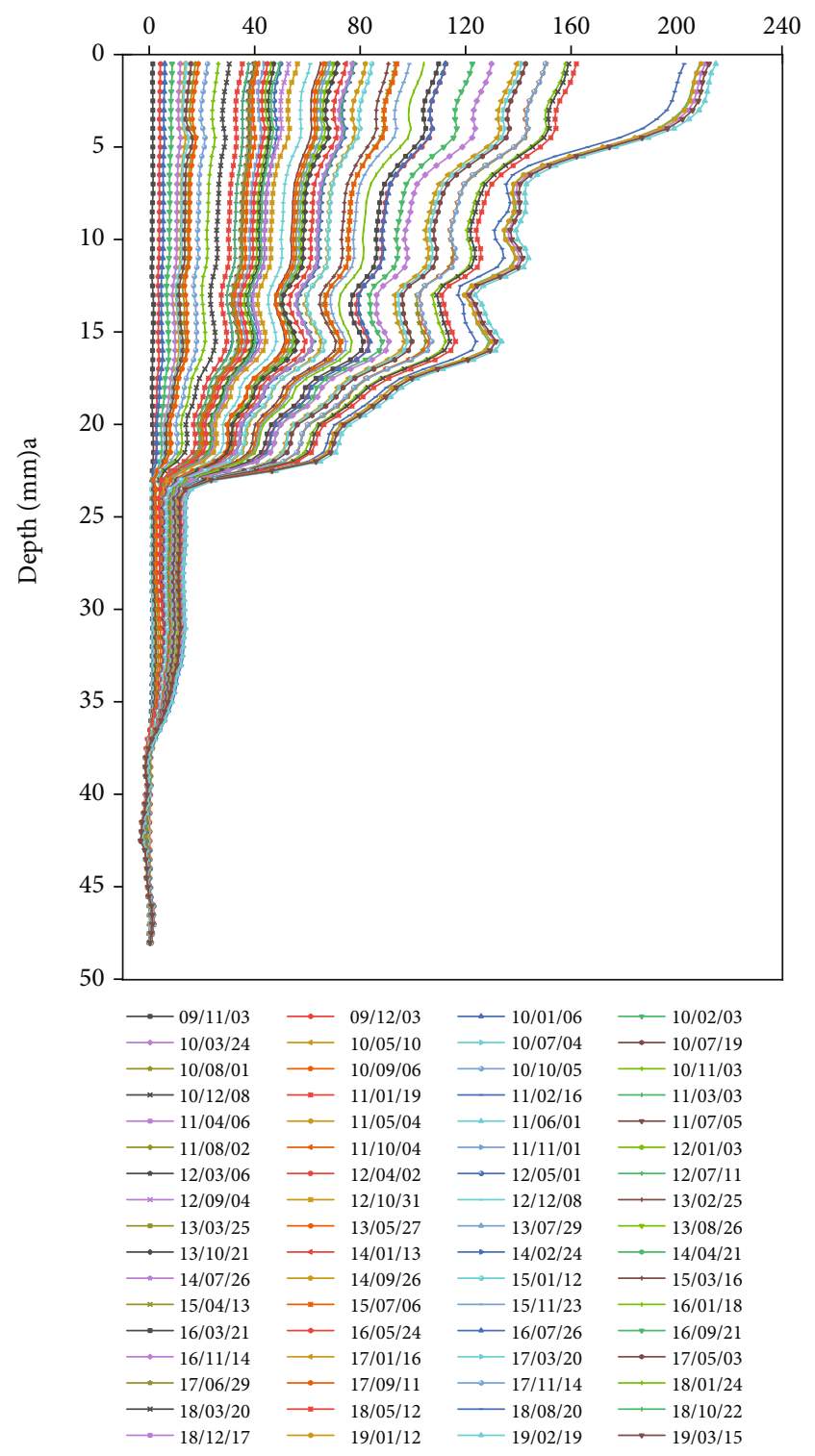

(a)

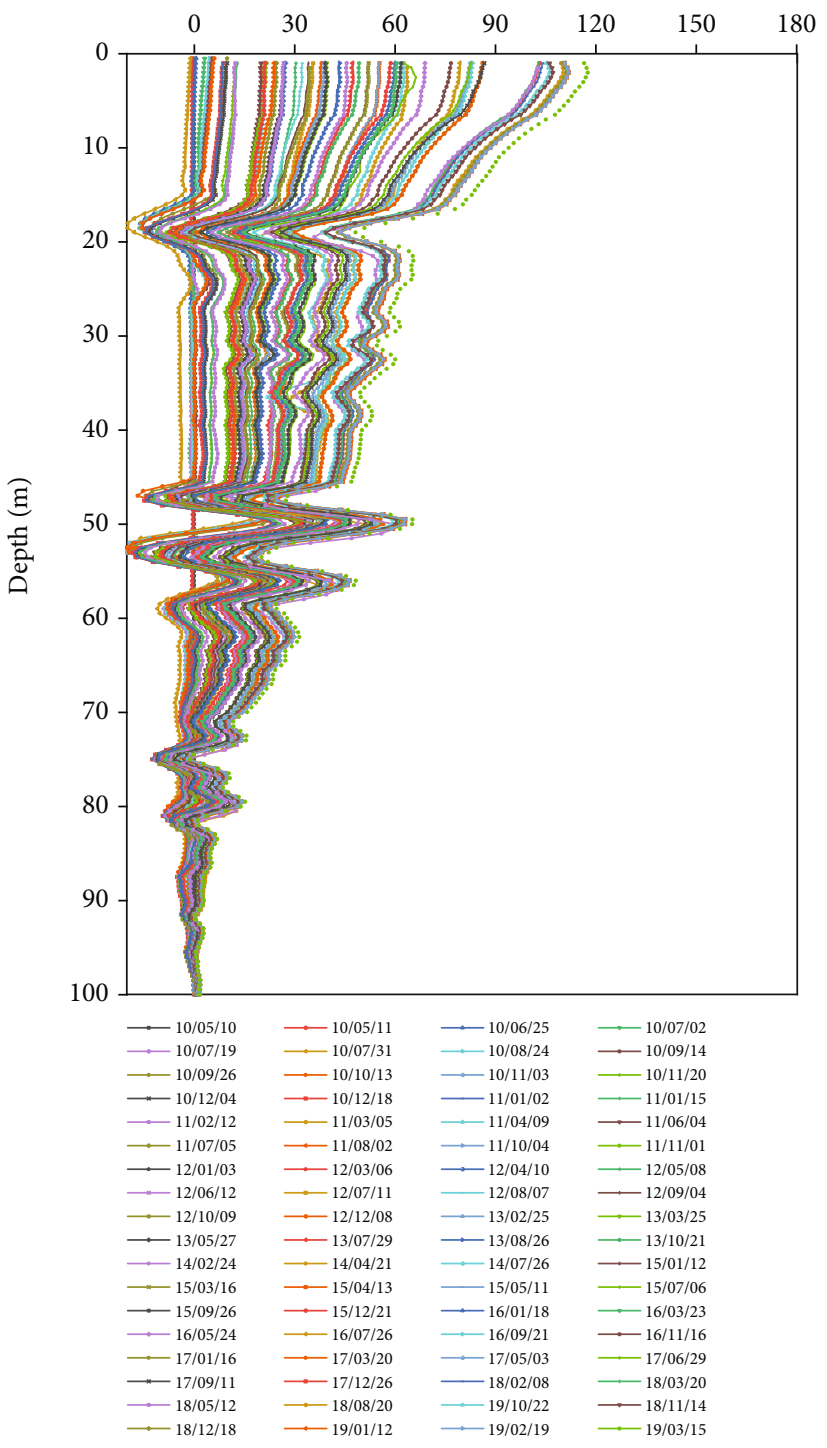

(b)

Figure 11: Continued. 


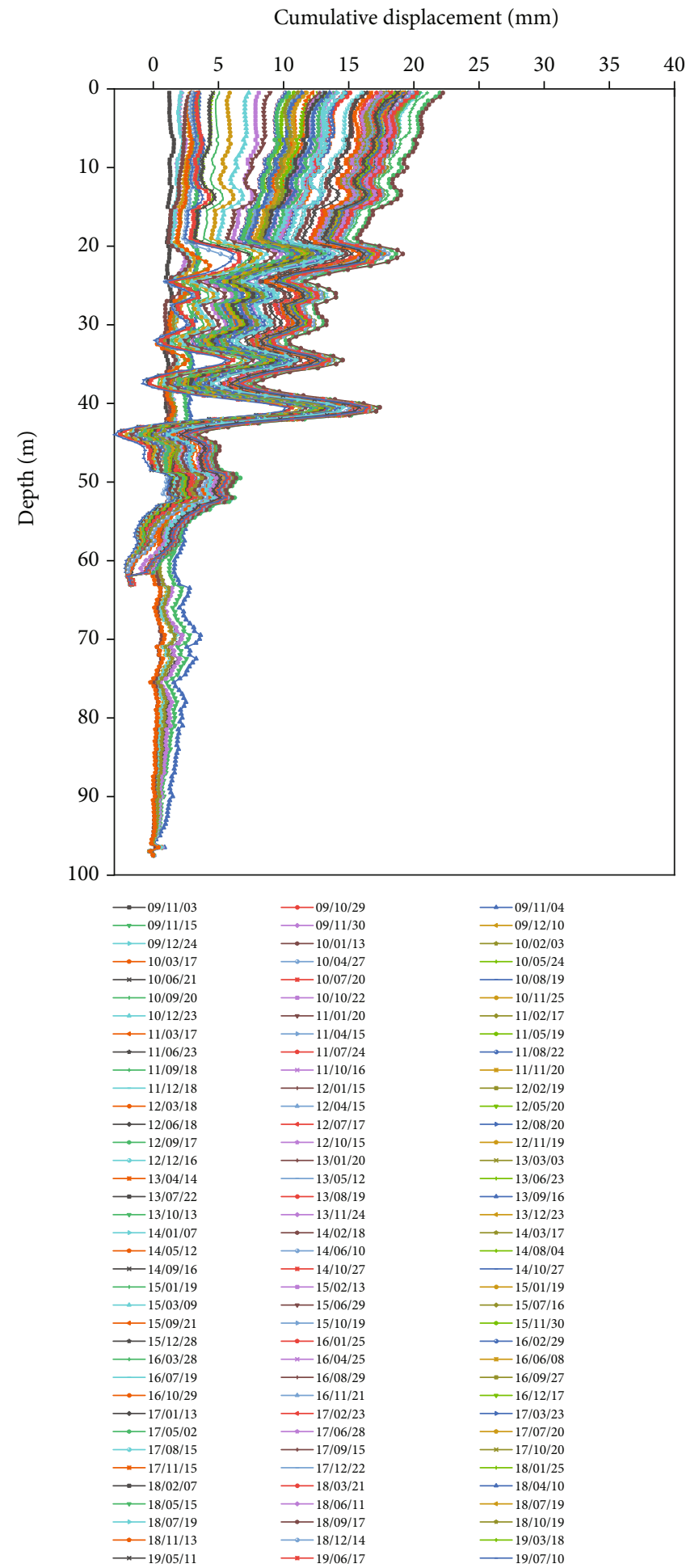

(c)

FIGURE 11: Monitoring curves of three inclinometers located at the cross-section A-A: (a) In01; (b) In10; (c) In06.

been formed. During this time, intermittent ground cracks in all areas have been reported since February 2003. Several long-lived extending in the direction of $\mathrm{N} 29^{\circ} \mathrm{E}$ tensile cracks with maximum widths and lengths of $10 \mathrm{~cm}$ and $150 \mathrm{~m}$, respectively, have been observed near the 980 to 1100 ma.s.l (Site.1 in Figure 2). In order to guarantee the stability and security of the PBGRS, a series of engineering control measures were applied according to emergency plans.

During the construction of the reinforcement measures in 2008, a small-scale collapse occurred at 974.5 ma.s.l (lower monitoring pile T04) in area II-2 (Site.2 in Figure 3). Due to the scraping of the lower deposits, a total volume is 


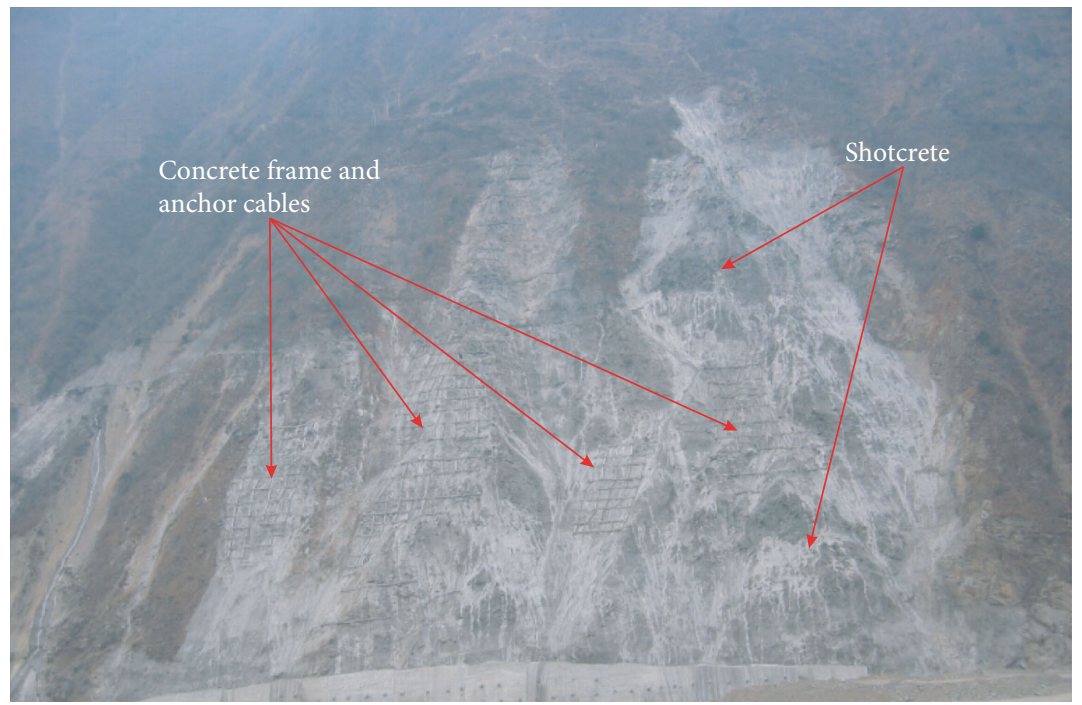

Figure 12: Reinforcement solution under construction as of 2015.

TABLE 3: Mechanical parameters of different strata in the PBGRS.

\begin{tabular}{|c|c|c|c|c|c|c|}
\hline Material & $\begin{array}{l}\text { Density } \\
\left(\mathrm{kg} / \mathrm{m}^{3}\right)\end{array}$ & $\begin{array}{l}\text { Elastic modulus } \\
(\mathrm{GPa})\end{array}$ & $\begin{array}{l}\text { Poisson's } \\
\text { ratio }\end{array}$ & $\begin{array}{c}\text { Friction angle } \\
\left({ }^{\circ}\right)\end{array}$ & $\begin{array}{l}\text { Cohesion } \\
(\mathrm{MPa})\end{array}$ & Yield criterion \\
\hline Colluvium deposit & 2250 & 0.3 & 0.38 & 30 & 0.06 & $\begin{array}{l}\text { Mohr- } \\
\text { Coulomb }\end{array}$ \\
\hline $\begin{array}{l}\text { Loosened and fractured } \\
\text { zone }\end{array}$ & 2600 & 0.6 & 0.34 & 32 & 0.28 & $\begin{array}{l}\text { Mohr- } \\
\text { Coulomb }\end{array}$ \\
\hline Heavily loosened zone & 2600 & 1.2 & 0.31 & 34 & 0.4 & $\begin{array}{l}\text { Mohr- } \\
\text { Coulomb }\end{array}$ \\
\hline Slightly fresh zone & 2600 & 10.0 & 0.29 & 43 & 1.2 & $\begin{array}{l}\text { Mohr- } \\
\text { Coulomb }\end{array}$ \\
\hline Slightly weathered basalt & 2650 & 12.0 & 0.28 & 46 & 1.3 & $\begin{array}{l}\text { Mohr- } \\
\text { Coulomb }\end{array}$ \\
\hline Alluvial deposit & 2200 & 0.8 & 0.32 & - & - & \\
\hline Artificial deposit & 2250 & 3.0 & 0.35 & - & - & \\
\hline
\end{tabular}

approximately $50 \mathrm{~m}^{3}$ and injured several workers. Several tensile cracks were observed in the collapse grooves formed in 2003 and 2004 (Site.2-1 in Figure 2). The dislocation cracks with an opening width of approximately $20 \mathrm{~cm}$ of drainage ditches (Site.2-2 in Figure 2).

On October 19, 2014, the local inspectors observed that fresh tension cracks (Site.3, Site.4, and Site.5 in Figure 2) appeared on the road to T15, and the width increased from $10 \mathrm{~cm}$ to $15 \mathrm{~cm}$ in the next two days. Since October 23, 16 groups of wooden piles have been buried on both sides of the edge crack to monitor the change trend of crack width. The typical P02 (Site.4 in Figure 2) and P05 crack change trends are shown in Figure 3, within 18 days of observation; the crack width at P05 increased from $20 \mathrm{~cm}$ to $28.2 \mathrm{~cm}$ (Figure 7).

In March 2015, several fresh tensile cracks are observed at around 1055 ma.s.l (Site.6 and Site.7 in Figure 2) with an opening width of approximately $5 \mathrm{~cm}-15 \mathrm{~cm}$ and length exceeding $100 \mathrm{~m}$, and the averaged strike nearby SN. An arc-shaped crack develops at 1010 to 1040 ma.s.l and extends to the old crack on the right side of the collapse groove formed in 2003, with a maximum opening width and sinking distance of $30 \mathrm{~cm}$ and $40 \mathrm{~cm}$, respectively.

\section{Monitoring Results}

5.1. Relative Surface Displacements. The first emergency mitigation was completed in September 2009. During the next four years monitoring period, the results of 12 surface displacement monitoring and reservoir water level changes are plotted in Figure 8. We can see that

(1) The cumulative displacement and average displacement velocities increased faster when the first impoundment was accomplished from 780 to 850 ma.s.l (Figure 9). Over the next 4 years, cumulative displacement increases slowly yearly. The cumulative displacement and average displacement velocities of T01 (approximately 980 ma.s.l) are much larger than other points, and their values are $152 \mathrm{~mm}$ (Figure 8), 


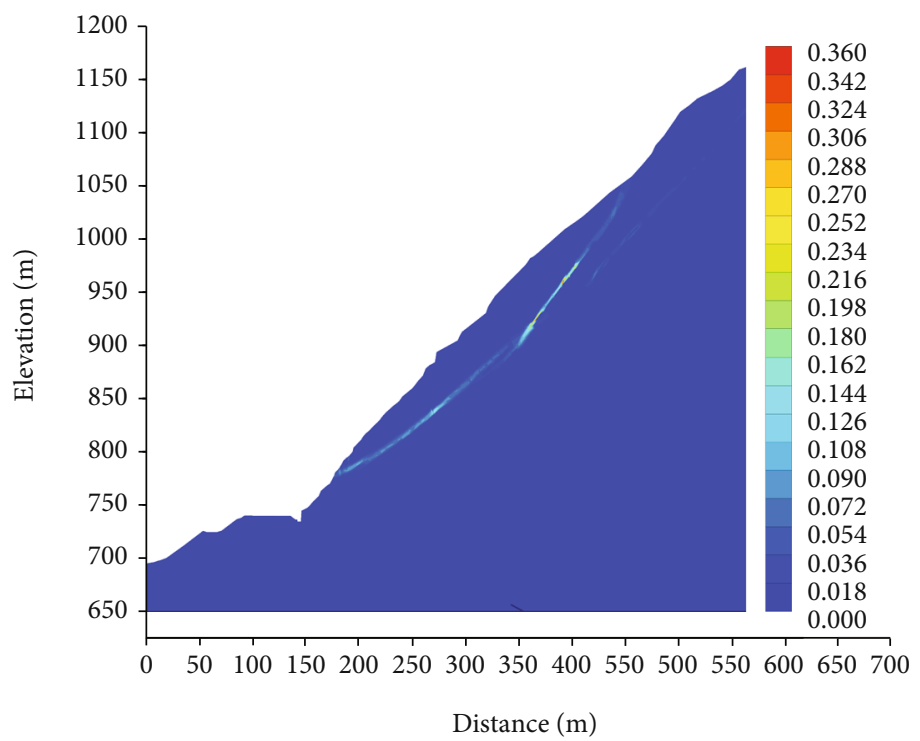

(a)

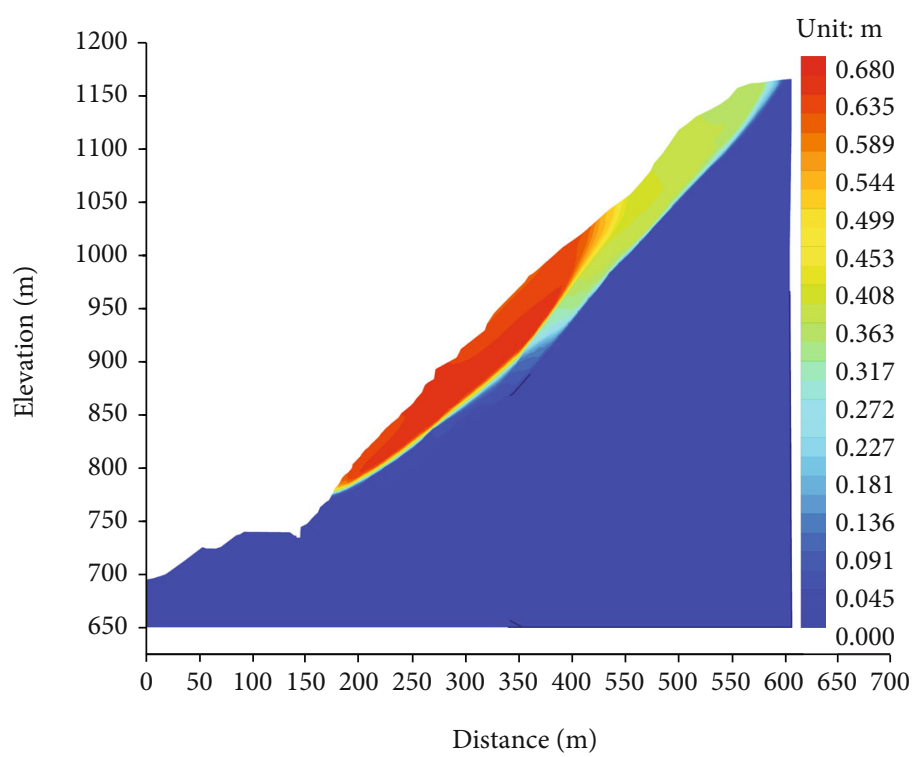

(b)

Figure 13: Continued. 


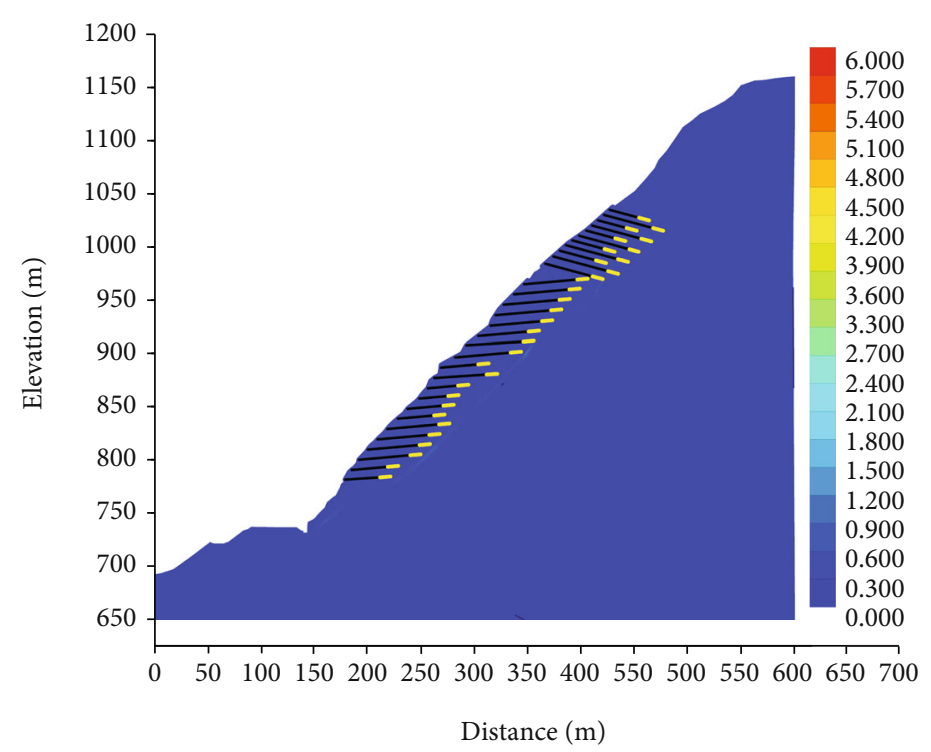

(c)

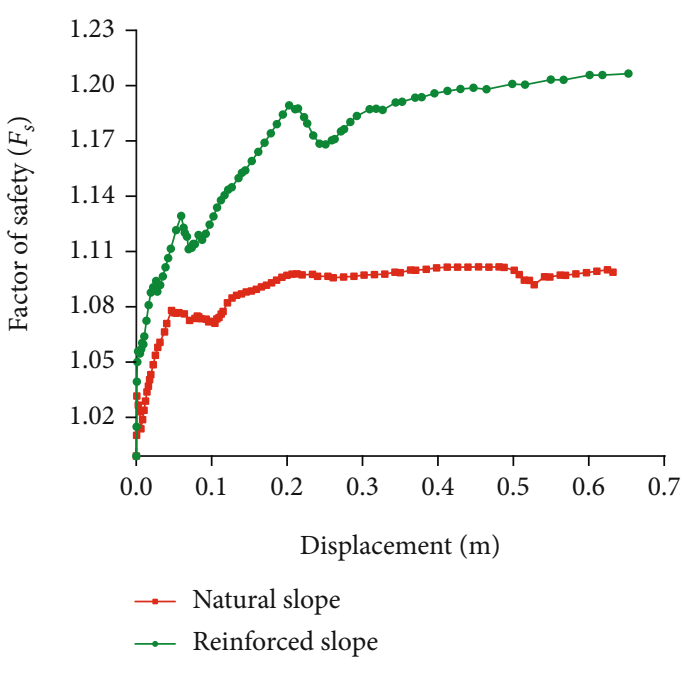

(d)

FIGURE 13: Numerical calculation results: $(\mathrm{a}, \mathrm{b})$ potential failure surface and the total displacement before the implementation of engineering measures; (c) potential shear surface reinforced by concrete frame combined with anchor cables; (d) factor of safety with pre- and postreinforcement measures.

$2.5 \mathrm{~mm} / \mathrm{month}$ (Figure 9(b)), and $2.3 \mathrm{~mm} / \mathrm{day}$ (Figure 9(a)), respectively, and T01 is located in the collapse groove formed in 2003 and 2004, respectively. This further suggests that area II- 1 is relatively unstable. Besides, the slope at T01 monitoring point is steep, and the surface layer mainly consists of eluvium and slope deposits, which is also the reason for the large displacement of T01. The overall monitoring data show that the cumulative displacement and average monthly and daily displacement velocities (Figure 8) vary gently, verifying the reinforced mitigation's effectiveness to decrease the deformation of the PBGRS

(2) The reservoir water level has a minor effect on surface displacement. This law can be explained by piezometers and reservoir water level results (Figure 10). The calculated water level (the sum of the pressure head and the buried elevation) of the two piezometers is almost the same as the reservoir water level. There is no head loss and lag, which proves loosened fractured rock mass and high permeability, and this rock mass structure is like a leaky bucket full of mesh

5.2. Inclinometer and Piezometer Measurements. The shear surface location can be obtained from an interpretation of inclinometric measurements [49-52]. The detailed data from 10 inclinometer monitors are shown in Figure 11, and Figure 2 shows the layout of inclinometers (A-A profiles in Figure 5(a)). According to the time-series deformation data, the subsurface movement was progressive over a continuous monitoring period of ten years. The cumulative displacement decreased towards the downslope, and the cumulative displacement at In06 is only $22 \mathrm{~mm}$ (Figure $11(\mathrm{c})$ ). For inclinometers In01, the shear surface is located at $22 \mathrm{~m}$, which coincides with the DH 01 . Notably, monitoring data from In10 indicates that the cumulative displacements at different depths were not uniform. There are at least 3 apparent shear surfaces at different depths, and the thickness of each surface is limited. A sawtooth-shaped cumulative displacement curve was observed at $40-60 \mathrm{~m}$, indicating that the rock mass in this area is loosened, and the relative dislocation is obvious. Besides, the shear surface at $22 \mathrm{~m}$ depth forms a continuous failure surface with the In01, and this result can be represented by the red line in Figure 2. Monitoring data from In06 show that the shear surface was located at a depth of approximately $40 \mathrm{~m}$ below the ground surface. Notably, relative dislocation can be clearly observed in the depth range of 20-40 $\mathrm{m}$, although these data values have some fluctuations. In view of the In01 (Figure 11(a)), In10 (Figure 11(b)), and In06 (Figure 11(c)) monitoring results, the cumulative displacement at the top of the inclinometers is $210 \mathrm{~mm}$, $119 \mathrm{~mm}$, and $22 \mathrm{~mm}$, respectively, indicating the zone in which In06 is located serves as a locked segment. The complete continuous failure surface is not formed in the A-A cross-section. Because the average displacement velocity of the In01 inclinometer was slow before July 2012, from May 2014 to August 2014, the average displacement velocity increased to $5 \mathrm{~mm} /$ month. Then, it decreased to $1.2 \mathrm{~mm} / \mathrm{month}$ in the next year. The most recent increase occurred from June 2018 to July 2018, and the cumulative displacement values increased from $167 \mathrm{~mm}$ to $202 \mathrm{~mm}$.

\section{Discussion}

6.1. Mechanisms and Formation Process of PBGRS. The rock mass of the PBGRS is found loosened and fractured, with the characteristic that is closely related to the regional tectonic event and the rapid down cutting caused by the river, which provides topographic conditions and abundant material 


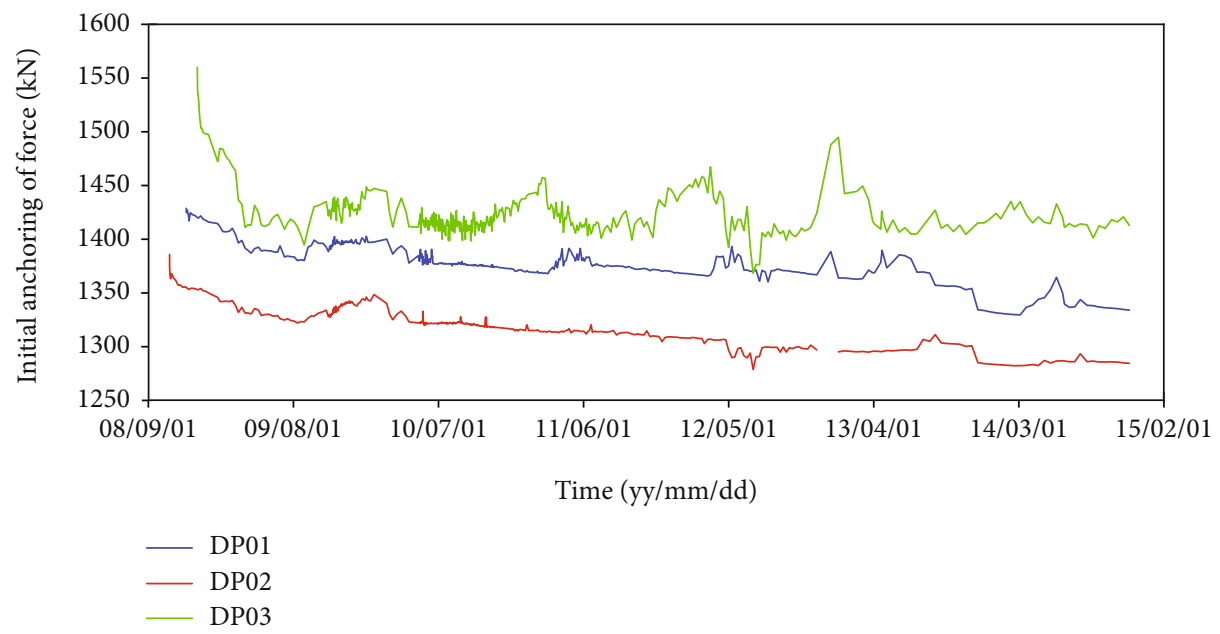

(a)

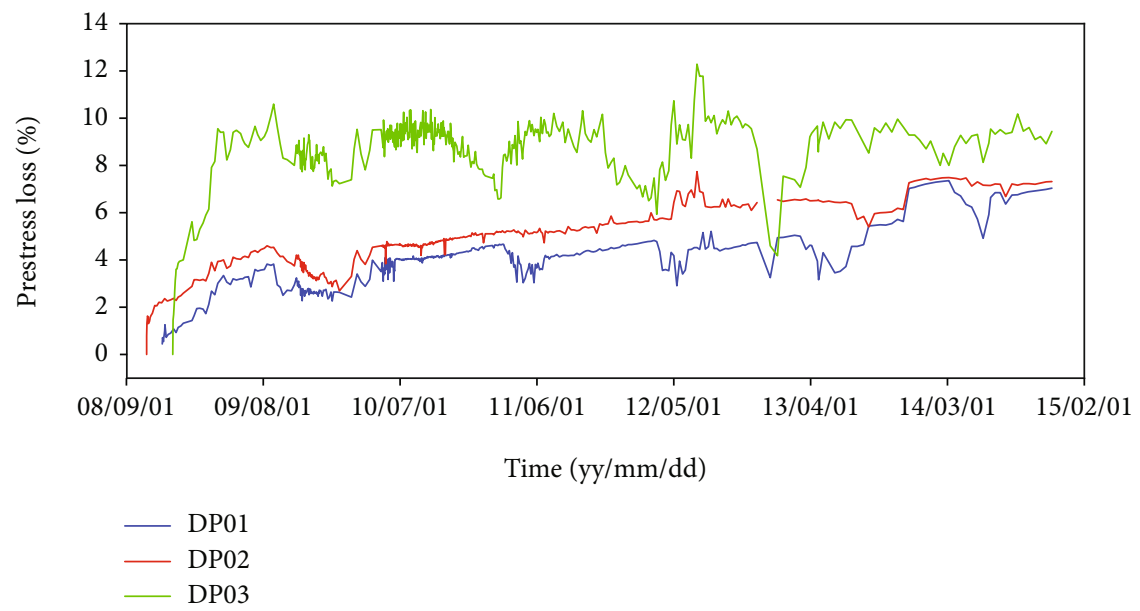

(b)

Figure 14: Typical monitoring results of anchor cable varied with time: (a) forces in anchor cables (3 measurement points); (b) force reduction of prestressed anchor cable (3 measurement points).

sources for the kinematic feasibility. Firstly, we present a geomechanical failure model for the PBRGS in area II-3 (Figure 3(a)). As discussed in "Brief History of Instabilities," excavation breaks the initial equilibrium conditions, which induced kinematic release. Besides, owning to broken rock mass, it is hard for relatively sliding mass to maintain integrity during creep. The tensile stress is high enough to crack the rock and induce new ruptures. Meanwhile, cracks create new free space for the posterior sliding mass and form channels for rainfall. Overall, area II-3 presents retrogressive disintegration deformation-failure mode.

The stability of the rock mass in area II-2 is most noting. To better understand the failure mechanism, inclinometer measurements may provide some evidence. According to Figure 11, the intermittent deformation trend indicates that the loosened fractured zone went through three stages: (1) sliding and compression cracking, (2) compaction due to the antislip effect of the locked segment, and (3) sliding and compression cracks again. After multiple cycles, a continuous shear surface is finally formed, and the destruction finally occurred; the free surface formed by the failure of the area II-
2 may promote the formation of high-altitude, extremely energetic rock avalanches. A more detailed analysis of the failure mechanism will be described later in the FEM verification section.

\subsection{Mitigation Measures and Effect Evaluation}

6.2.1. Mitigation Measures. Based on extensive field surveys and continuous monitoring results, the leading engineering reinforcement measures, including concrete frame combined with anchor cables, large area concrete shotcrete, and intercepting ditch, were applied to stabilize the PBGRS (Figure 12). The premise of these reinforcement measures is to remove loose deposits on the surface. The total length of the anchor cable is between 45 and $70 \mathrm{~m}$. The single anchor cable $(10 \times \varphi 15.2$ unbonded steel stranded wire $)$ is designed to have an anchoring force of $1500 \mathrm{kN}$, with a standard area and density of $140 \mathrm{~mm}^{2}$ and $1101 \mathrm{~kg} / \mathrm{km}$, respectively. The tensile strength is $1860 \mathrm{MPa}$, the elastic modulus is $1.95 \times$ $10^{5} \mathrm{MPa}$, and the anchor hole diameter is $140 \mathrm{~mm}$. The emergency mitigation plan was divided into two phases: The first 
stage is mainly aimed at the water level fluctuation zone with 780-850 ma.s.l. To obtain maximum antisliding force, the anchoring angle of the anchor cables is tilted up $5^{\circ}$, which the engineering audit was completed in October 2009. Based on ensuring the loosened fractured zone's stability, in the second stage treatment, the anchoring angle is inclined downward $15^{\circ}$. As of September 2015, 912 anchor cables have been implemented, and 1020 anchor cables have not been completed.

6.2.2. The FEM Verification. The purpose of the numerical analysis is to evaluate the PBGRS stability after the installation of reinforcement measures. Since no major discontinuities were recognized as well as the deformation characteristics were similar to the particles, the slope rock mass was modeled as a continuous material [1]. Many studies pointed out that rock slopes with faults and joints; the strength reduction FEM can provide more accurate stability evaluation results [53-55].

The geologic engineering profile A-A (Figure 5(a)) was analyzed. The total numbers of the elements and nodes in the mesh for the strength reduction FEM were 17743 and 18045 , respectively. The boundary conditions of the model are as follows: left and right boundaries limit horizontal displacement, and the bottom boundary is fixed. The selection of material parameters is based on the "Deformation Mechanism and Stability Evaluation of Rock Slope on the Right Bank of Pubugou Hydropower Station" [56]. The MohrCoulomb model was applied in the loosened fractured zone, heavily loosened zone, moderately loosened zone, and colluviums. Due to the alluvial deposits and artificial deposits at the toe of the slope which are far away from the research area of interest in this article, to avoid untimely yielding during the calculation, these areas use linearly elastic mode constitutive. The detailed material parameters and constitutive components used in the FEM are shown in Table 3.

6.2.3. Analysis Results. Figures 13(a) and 13(b) show the calculation results without reinforcement measures. As expected, the predicted failure surface mainly occurs at the bottom of the loosened fractured zone (780-1050 ma.s.l). Above the 950 ma.s.l, a discrete shear surface appears at the bottom of the heavily loosened zone. From the numerical simulation results, we can predict if the PBGRS does not take reinforcement measures, and with continuous dislocation deformation. Finally, the loosened fractured zone was completely cut-off to form a huge slide body and a new head scarp. After adopting the concrete frame combined with anchor cables, the FEM results are shown in Figure 13(c). The continuous shear surface in a loosened fractured zone was effectively blocked. The most dangerous shear surface moves around the anchor cables to the bottom of the heavily loosened zone but only forms the partially discrete shear surface, so anchor cables also improve the stability of the heavily loosened zone. By comparing pre- and postreinforcement measures of concrete frames and ground anchors, safety increased from 1.09 to 1.21 (Figure $13(\mathrm{~d})$ ), which basically meets the 2012 Professional Standards of the People's Republic of China.
6.2.4. Monitoring Data Verification and Recommendations. As shown in Figure 14, the anchor cable generally experienced relatively minor relaxation and less than $13 \%$ in 7 years. Although these analyses prove that the reinforcement measures are very effective, most anchor cables do not penetrate the heavily loosened zone and cause discontinuous shear surfaces. The dislocation still went on due to shearing, and the main zone of movement is concentrated in area I (Figure 11(a)). We still recommend that the anchor cables should be long enough to extend as far as possible into the more stable zone (such as bedrock). Besides, the remaining 1020 anchor cables should be implemented as soon as possible.

\section{Conclusions}

This paper studies a case of the stabilization of a high and steep rock slope, characterized by a highly jointed and fractured rock mass. The main culprit for the relaxation of the rock mass can boil down to the rapid down cutting caused by the river. Extensive investigations have shown that small-scale excavation is considered an essential factor that causes PBGRS movement. Drilling data and monitoring inclinometer displacement show that there is multiple shear surface inside the rock mass. The whole PBGRS underwent slow creep deformation in the loosened fractured zone. The movement occurred locally in the PBRRS, and the entire rock slope did not form a continuous shear surface. The position of failure at the toe of the slope in 2003 (area II-1) is considered a typical retrogressive motion mode. The stability of the toe is vital because it plays an essential supporting role. As revealed by the inclinometer displacement, the PBGRS would probably deform in a complex pattern: progressive compression-induced rupture occurred in the loosened fractured zone. The lower locked segment is continuously squeezed. With the interval movement cycle, PBGRS stability will be gradually worsening even a loosened fractured zone will form a continuous cut-out channel. The concrete frame combined with anchor cables has been performed and come into effect, and comparative analysis was carried out on the PBGRS before and after reinforcement measures. As revealed by the results, the potential shear surface is in the loosed fractured zone. After the anchor cables are applied, the stability of the slope is much improved. Finally, the piezometer data show that the reservoir water level has a minor effect on the PBGRS deformation, due to the extensively fractured rock mass and high permeability of the rock mass, which is beneficial to the good operation of the PBG.

\section{Data Availability}

The data used to support the results of this research are available from the corresponding author upon request.

\section{Conflicts of Interest}

None of the authors have any conflicts of interest. 


\section{Acknowledgments}

This research is financially supported by the Open Fund of State Key Laboratory of Geological Disaster Prevention and Geological Environment Protection (Grant No. SKLGP2018K011) and the National Natural Science Foundation of China (Grant No. 41907225).

\section{References}

[1] T. Chen, J. H. Deng, N. Sitar et al., "Stability investigation and stabilization of a heavily fractured and loosened rock slope during construction of a strategic hydropower station in China," Engineering Geology, vol. 221, pp. 70-81, 2017.

[2] S. L. Zhang, Z. H. Zhu, S. C. Qi, Y. X. Hu, Q. du, and J. W. Zhou, "Deformation process and mechanism analyses for a planar sliding in the Mayanpo massive bedding rock slope at the Xiangjiaba hydropower station," Landslides, vol. 15, no. 10, pp. 2061-2073, 2018.

[3] Y. Sun, J. S. Huang, W. Jin, S. W. Sloan, and Q. H. Jiang, "Bayesian updating for progressive excavation of high rock slopes using multi- type monitoring data," Engineering Geology, vol. 252, pp. 1-13, 2019.

[4] D. Q. Li, S. H. Jiang, Z. J. Cao, C. B. Zhou, X. Y. Li, and L. M. Zhang, "Efficient 3-D reliability analysis of the $530 \mathrm{~m}$ high abutment slope at Jinping I hydropower station during construction," Engineering Geology, vol. 195, pp. 269-281, 2015.

[5] J. W. Chen, J. H. Deng, J. B. Wei, X. Y. Wu, and A. C. Zhang, "Cause analysis of cracking in right abutement slope of Changheba hydropower station," Chinese Journal of Rock Mechanics and Engineering, vol. 31, no. 6, pp. 1121-1127, 2012.

[6] S. R. Sun, C. Q. Gao, J. M. Liu, Y. X. Lu, and P. L. Xu, "Research on formation mechanism of deep cracks in left bank slope of Jinping first stage hydropower station based on DDA method," Applied Mechanics and Materials, vol. 170-173, pp. 1966-1970, 2012.

[7] G. Rong, J. Peng, X. J. Wang, G. Liu, and D. Hou, "Formation mechanism of deep cracks in the left bank slope of Jinping-i hydropower station," Disaster Advances, vol. 6, no. 3, pp. 413, 2013.

[8] S. W. Qi, F. Q. Wu, F. Z. Yan, and H. X. Lan, "Mechanism of deep cracks in the left bank slope of Jinping first stage hydropower station," Engineering Geology, vol. 73, no. 1-2, pp. 129-144, 2004.

[9] J. G. Um and P. H. S. W. Kulatilake, "Kinematic and block theory analyses for shiplock slopes of the Three Gorges Dam site in China," Geotechnical and Geological Engineering, vol. 19, no. 1, pp. 21-42, 2001.

[10] D. X. Zhang, G. H. Wang, T. J. Yang, M. C. Zhang, S. H. Chen, and F. Y. Zhang, "Satellite remote sensing-based detection of the deformation of a reservoir bank slope in Laxiwa hydropower station, China," Landslides, vol. 10, no. 2, pp. 231-238, 2013.

[11] Y. P. Yin, B. L. Huang, W. P. Wang et al., "Reservoir-induced landslides and risk control in Three Gorges project on Yangtze River, China," Journal of Rock Mechanics and Geotechnical Engineering, vol. 8, no. 5, pp. 577-595, 2016.

[12] Y. G. Zhang, Z. Zhang, S. Xue, R. Wang, and M. Xiao, "Stability analysis of a typical landslide mass in the Three Gorges reservoir under varying reservoir water levels," Environmental Earth Sciences, vol. 79, no. 1, 2020.
[13] Y. G. Zhang, S. Y. Zhu, J. K. Tan, L. D. Li, and X. J. Yin, "The influence of water level fluctuation on the stability of landslide in the Three Gorges reservoir," Arabian Journal of Geosciences, vol. 13, no. 17, p. 845, 2020.

[14] Y. G. Zhang, Y. Zhu, W. Q. Zhang, and H. Liu, “Analysis of deformation characteristics and stability mechanisms of typical landslide mass based on the field monitoring in the Three Gorges reservoir, China," Journal of Earth System Science, vol. 128, no. 1, pp. 2-11, 2019.

[15] Y. P. Yin, B. L. Huang, X. Chen, G. N. Liu, and S. C. Wang, "Numerical analysis on wave generated by the Qianjiangping landslide in Three Gorges reservoir, China," Landslides, vol. 12, no. 2, pp. 355-364, 2015.

[16] C. J. Ouyang, H. C. An, S. Zhou et al., "Insights from the failure and dynamic characteristics of two sequential landslides at Baige village along the Jinsha River, China," Landslides, vol. 16, no. 7, pp. 1397-1414, 2019.

[17] J. J. Clague, S. G. Evans, and I. G. Blown, “A debris flow triggered by the breaching of a moraine-dammed lake, Klattasine Creek, British Columbia," Canadian Journal of Earth Sciences, vol. 22, no. 10, pp. 1492-1502, 1985.

[18] G. Barla and P. Paronuzzi, “The 1963 Vajont landslide: 50th anniversary," Rock Mechanics and Rock Engineering, vol. 46, no. 6, pp. 1267-1270, 2013.

[19] D. Xue, T. Li, S. Zhang, C. C. Ma, M. B. Gao, and J. Liu, "Failure mechanism and stabilization of a basalt rock slide with weak layers," Engineering Geology, vol. 233, pp. 213-224, 2018.

[20] S. L. Luo, X. G. Jin, and D. Huang, "Long-term coupled effects of hydrological factors on kinematic responses of a reactivated landslide in the Three Gorges reservoir," Engineering Geology, vol. 261, article 105271, 2019.

[21] J. Corominas and J. Moya, "Reconstructing recent landslide activity in relation to rainfall in the Llobregat River basin, Eastern Pyrenees, Spain," Geomorphology, vol. 30, no. 1-2, pp. 7993, 1999.

[22] T. L. Tsai, "The influence of rainstorm pattern on shallow landslide," Environmental Geology, vol. 53, no. 7, pp. 15631569, 2008.

[23] D. Huang, D. M. Gu, Y. X. Song, D. F. Cen, and B. Zeng, "Towards a complete understanding of the triggering mechanism of a large reactivated landslide in the Three Gorges reservoir," Engineering Geology, vol. 238, pp. 36-51, 2018.

[24] S. Matsuura, S. Asano, and T. Okamoto, "Relationship between rain and/or meltwater, pore-water pressure and displacement of a reactivated landslide," Engineering Geology, vol. 100, pp. 49-59, 2008.

[25] S. W. Qi, F. Z. Yan, S. J. Wang, and R. C. Xu, "Characteristics, mechanism and development tendency of deformation of Maoping landslide after commission of Geheyan reservoir on the Qingjiang River, Hubei Province, China," Engineering Geology, vol. 86, no. 1, pp. 37-51, 2006.

[26] J. G. Liu, P. J. Mason, N. Clerici et al., "Landslide hazard assessment in the Three Gorges area of the Yangtze river using ASTER imagery: Zigui-Badong," Geomorphology, vol. 61, no. 1-2, pp. 171-187, 2004.

[27] C. Irigaray, F. Lamas, R. el Hamdouni, T. Fernández, and J. Chacón, "The importance of the precipitation and the susceptibility of the slopes for the triggering of landslides along the roads," Natural Hazards, vol. 21, no. 1, pp. 65-81, 2000.

[28] F. Y. Zhang, S. B. Bai, G. Liu, W. W. Chen, and W. F. Han, "Process and mechanisem of cut slope instablity at yuan 
jiawan section of lan-expressway," Journal of Engineering Geology, vol. 1, pp. 83-89, 2009.

[29] Y. P. Yin, "Seepage pressure effect on landslide stability at the Three Gorges. Reservoir area," The Chinese Journal of Geological Hazard and Control, vol. 14, no. 3, pp. 1-8, 2003.

[30] Y. P. Yin and X. M. Peng, "Failure mechanism on Qianjiangping landslide in the Three Gorges reservoir region," Hydrogeology and Engineering Geology, vol. 3, pp. 51-54, 2007.

[31] W. Yi, Z. P. Meng, and Q. L. Yi, "Theory and method of landslide stability prediction in the Three Gorges reservoir area," Science Press, Beijing, 2011.

[32] X. L. Hu, M. Zhang, M. J. Sun, K. X. Huang, and Y. J. Song, "Deformation characteristics and failure mode of the Zhujiadian landslide in the Three Gorges reservoir, China," Bulletin of Engineering Geology and the Environment, vol. 74, no. 1, pp. 1-12, 2015.

[33] D. M. Gu and D. Huang, “A complex rock topple-rock slide failure of an anaclinal rock slope in the Wu Gorge, Yangtze River, China," Engineering Geology, vol. 208, pp. 165-180, 2016.

[34] D. Huang and D. M. Gu, "Influence of filling-drawdown cycles of the Three Gorges reservoir on deformation and failure behaviors of anaclinal rock slopes in the Wu Gorge," Geomorphology, vol. 295, pp. 489-506, 2017.

[35] M. Xia, G. M. Ren, and X. L. Ma, "Deformation and mechanism of landslide influenced by the effects of reservoir water and rainfall, Three Gorges, China," Natural Hazards, vol. 68, no. 2, pp. 467-482, 2013.

[36] L. L. Zheng, Y. F. Zheng, L. M. Zhang, X. Li, and J. H. Wang, "Probabilistic model calibration for soil slope under rainfall: effects of measurement duration and frequency in field monitoring," Natural Hazards, vol. 64, no. 5, pp. 365-378, 2014.

[37] T. Peraya, X. Shi, L. Zhang, T. Balz, and M. S. Liao, "Characterization of landslide deformations in three gorges area using multiple InSAR data stacks," Remote Sensing, vol. 5, no. 6, pp. 2704-2719, 2013.

[38] M. Jaboyedoff, T. Oppikofer, A. Abellán et al., "Use of LIDAR in landslide investigations: a review," Natural Hazards, vol. 61, no. 1, pp. 5-28, 2012.

[39] G. B. Crosta, P. Frattini, and F. Agliardi, "Deep seated gravitational slope deformations in the European Alps," Tectonophysics, vol. 605, pp. 13-33, 2013.

[40] I. P. Kovács, S. Czigány, B. Dobre et al., “A field survey-based method to characterise landslide development: a case study at the high bluff of the Danube, south-central Hungary," Landslides, vol. 16, no. 8, pp. 1567-1581, 2019.

[41] S. Uhlemannab, A. Smithc, J. Chambersa et al., "Assessment of ground-based monitoring techniques applied to landslide investigations," Geomorphology, vol. 253, pp. 438-451, 2019.

[42] U. Niethammer, M. R. James, S. Rothmund, J. Travelletti, and M. Joswig, "UAV-based remote sensing of the Super-Sauze landslide: evaluation and results," Engineering Geology, vol. 128, pp. 2-11, 2012.

[43] E. Intrieri, F. Raspini, A. Fumagalli et al., "The Maoxian landslide as seen from space: detecting precursors of failure with Sentinel-1 data," Landslides, vol. 15, pp. 123-133, 2017.

[44] J. Wasowski and F. Bovenga, "Investigating landslides and unstable slopes with satellite multi temporal interferometry: current issues and future perspectives," Engineering Geology, vol. 174, pp. 103-138, 2014.
[45] R. Q. Huang, "Geodynamical process and stability control of high rock slope development," Chinese Journal of Rock Mechanics and Engineering, vol. 27, no. 8, pp. 1525-1544, 2008.

[46] S. W. Song, X. M. Feng, B. Y. Xiang, W. B. Xing, and Y. Zeng, "Research on key technologies for high and steep rock slopes of hydropower engineering in southwest China," Chinese Journal of Rock Mechanics and Engineering, vol. 30, no. 1, pp. 1-22, 2011.

[47] D. Huang, R. Q. Huang, Q. Chen, M. Zhang, and L. W. Jiang, "Study on distribution laws of observation full-trace length of basal joints," Hydrogeology and Engineering Geology, vol. 4, pp. 10-12, 2005.

[48] M. Mauldon, "Estimating mean fracture trace length and density from observations in convex windows," Rock Mechanics and Rock Engineering, vol. 31, no. 4, pp. 201-216, 1998.

[49] N. M. Pinyol, E. E. Alonso, J. Corominas, and J. Moya, "Canelles landslide: modelling rapid drawdown and fast potential sliding," Landslides, vol. 9, no. 1, pp. 33-51, 2012.

[50] D. F. Macfarlane, "Observations and predictions of the behaviour of large, slow-moving landslides in schist, Clyde Dam reservoir, New Zealand," Engineering Geology, vol. 109, no. 1-2, pp. 5-15, 2009.

[51] L. Borgatti, A. Corsini, M. Barbieri et al., "Large reactivated landslides in weak rock masses: a case study from the Northern Apennines (Italy)," Landslides, vol. 3, no. 2, pp. 115-124, 2006.

[52] S. Jiang, Y. F. Wang, C. Tang, and K. Liu, "Long-term kinematics and mechanism of a deep-seated slow-moving debris slide near Wudongde hydropower station in southwest China," Journal of Mountain Science, vol. 15, no. 2, pp. 364-379, 2018.

[53] S. Y. Zhao, Y. R. Zheng, and W. D. Deng, "Stability analysis on jointed rock slope by strength reduction FEM," Chinese Journal of Rock Mechanics and Engineering, vol. 22, no. 2, pp. 254-260, 2003.

[54] G. Q. Chen, R. Q. Huang, Q. Xu, T. B. Li, and M. L. Zhu, "Progressive modelling of the gravity-induced landslide using the local dynamic strength reduction method," Journal of Mountain Science, vol. 10, no. 4, pp. 532-540, 2013.

[55] E. E. Alonso and N. M. Pinyol, "Criteria for rapid sliding I. A review of Vaiont case," Engineering Geology, vol. 114, no. 34, pp. 198-210, 2010.

[56] Hydrochina Chengdu Engineering Corporation, Deformation Mechanism and Stability Evaluation of Rock Slope on the Right Bank of Pubugou Hydropower Station, Hydrochina Chengdu Engineering Corporation, Dadu River in Sichuan Province, 2015. 